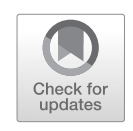

\title{
Detecting the Diagnosis: Parasitology, Crime Fiction, and the British Medical Gaze
}

In 1905, Dr Charles Porter, medical officer of health for Johannesburg, gave an illustrated lecture at St Andrew's church literary society in Sheffield. The subject was 'some animal parasites of the blood' which, as reported by the Sheffield Daily Telegraph, he had chosen because he had 'often wished to compare doctors and detectives'. He asserted that he

couldn't understand why writers of fiction went to the art of detection instead of the science of medicine for their mysteries and romances, neither did he know why the detective of fiction was provided with a halo of romance. ${ }^{1}$

Porter held a diploma in Public Health in addition to his Doctor of Medicine (MD) and Bachelor of Surgery (ChB). He qualified as a Barristerat-Law at Gray's Inn in 1898 before taking up his post in Johannesburg, after the city had been occupied by British troops during the Anglo-Boer war (1899-1902). ${ }^{2}$ In his lecture, he discussed malaria and sleeping sickness, suggesting that such subjects were worthy of appearing in mysteries and romances, and yet that the work of famous parasitologists

\footnotetext{
1 'St Andrew's Literary Society' Sheffield Daily Telegraph, Friday 24 March 1905, p. 4.

${ }^{2}$ C. Plug, 'Porter, Dr Charles (Public Health)' S2A3 Biographical Database of Southern African Science http://www.s2a3.org.za/bio/Biograph_final.php?serial=2232 [accessed 2 September 2020].
}

(C) The Author(s) 2022

E. Taylor-Pirie, Empire Under the Microscope, Palgrave Studies in Literature, Science and Medicine, https://doi.org/10.1007/978-3-030-84717-3_4 
like Patrick Manson and Ronald Ross (whom he names) is wholly different to that carried out by the detectives who usually grace such fiction. ${ }^{3}$

To a modern reader, this comment might seem bizarre. After all, the rhetorical and material confluences between doctors and detectives are, for us, par for the course. Notwithstanding the blurring of professions practised by forensic pathologists and coroners, detective work has 'long been a metaphor for clinical acumen'. ${ }^{4}$ As Claudio Rapezzi et al. point out, this is due to the real or imagined parallels between the professions, both of which 'try to restore a status quo' disrupted by crime or disease, using 'deterministic interpretation[s] of clues, signs, and symptoms' that 'are often meaningless or disconcerting to the layman'. ${ }^{5}$ These imagined parallels were popularised by Sherlock Holmes, perhaps the most enduring archetype of the scientific detective. As Arthur Conan Doyle reflected in 1930, his creation of Holmes was directly inspired by his medical training. His goal was to create a detective who 'would treat crime as Dr Bell [his mentor] treated disease' and 'where science would take the place of chance'. ${ }^{6}$ Such a goal articulates, in Jon Thompson's words, 'a desire for a complete form of knowledge' that reflects the developing 'scientific' mode of knowledge that revolutionised modern American, and British, culture at the end of the nineteenth century. ${ }^{7}$

The idea that science provides a 'complete' knowledge is a fantasy that has become a truism in the popular imagination. Holmes quickly breached the bounds of Conan Doyle's literary experiment and emerged as a figure that helped to reshape the public understanding and authority of scientific knowledge at the fin de siècle. As I explore in this chapter, the 'halo of romance' that Porter associates with detective fiction was not confined to the literary realm, nor was it a straightforward reflection of literary artifice, but rather, was part of the complex negotiation between science as idealisation and science as material practice. In his 2007 textbook on evidencebased medicine (EBM), Swedish professor of surgery Jorgen Nordenstrom

\footnotetext{
${ }^{3}$ Porter was perhaps prompted to use this frame of reference by the publication of The Return of Sherlock Holmes a few weeks previously on 7th March.

${ }^{4}$ Claudio Rapezzi, Roberto Ferrari, and Angelo Branzi, 'White Coats and Fingerprints: Diagnostic Reasoning in Medicine and Investigative Methods of Fictional Detectives’ British Medical Journal 331 (22 December 2005): https://doi.org/10.1136/bmj.331.7531.1491.

${ }^{5}$ Ibid.

${ }^{6}$ London, British Library. Early Spoken Word Recordings. 1CL0013693. 'Conan Doyle Speaking 1 of 2', 14 May 1930.

${ }^{7}$ Jon Thompson, Fiction, Crime and Empire: Clues to Modernity and Postmodernism (Chicago: University of Illinois Press, 1993) pp. 44-45.
} 
claims a similarity between EBM and detective work. He draws particular attention to the importance of 'reasoning backwards' through time-a technique that Sherlock Holmes employs; 'The grand thing is to be able to reason backwards', Holmes announces to Watson in A Study in Scarlet (1887). ${ }^{8}$ Holmes considers reasoning backwards synonymous with reasoning 'analytically' and further explains: 'being given a result and having the ability to evolve from [one's] inner consciousness what the steps were which led up to that result'. Despite crediting the pedagogical technique of 'backwards reasoning' to 'Barrows at McMaster University in the 1970s', Nordenstrom places EBM in dialogue with Conan Doyle's fictional detective by choosing the title: Evidence-Based Medicine: In Sherlock Holmes' Footsteps, by including several literary quotations from the canon, and by employing a heavy-handed use of analogy. As Paul Glasziou, professor of EBM at the University of Oxford, notes in the foreword: using Holmes as a reference point makes the book 'very accessible'.

Articles and editorials in medical journals confirm that Holmes is still widely considered to be a useful tool in medical education and clinical practice. ${ }^{10}$ Indeed, the invocation of Holmesian detection in scientific articles is ubiquitous. ${ }^{11}$ Many see Holmes as a paragon of good diagnostic practice; Michael Trimble and Paul Hamilton quote Holmes twice in their

\footnotetext{
${ }^{8}$ Arthur Conan Doyle, A Study in Scarlet (1887; London: Ward, Lock and Co., $1893)$ p. 93.

${ }^{9}$ Jorgen Nordenstrom, Evidence-Based Medicine: In Sherlock Holmes' Footsteps (Oxford: Blackwell Publishing, 2007) p. vi.

${ }^{10}$ See, for example, Larry Miller, 'Sherlock Holmes's Methods of Deductive Reasoning
} Applied to Medical Diagnostics' Western Journal of Medicine 142.3 (March 1985) 413-14; André Didierjean and Fernand Gobet, 'Sherlock Holmes - An Expert's View of Expertise' British Journal of Psychology 99 (2008) 109-25 (p. 109); Beryl B. Benacerraf, 'The Sherlock Holmes Approach to Diagnosing Fetal Syndromes by Ultrasound' Clinical Obstetrics and Gynaecology 55.1 (2012) 226-48; A. Schattner, 'Sherlock Holmes and Clinical Excellence' QJM: An International Journal of Medicine 106.12 (December 2013) 1157; G. V. Chanukya, M. Mengade, J. Goud. I.S. Rao, A. Jain, 'Tumor-Induced Osteomalacia: A Sherlock Holmes Approach to Diagnosis and Management' Annals of MaxillofacialSurgery 7.1 (2017) 143-47.

${ }^{11}$ Some authors simply abandon a quotation from a Holmes story at the beginning of a section and fail to engage with it in the prose at all. Perhaps because they feel it speaks for itself. See for example: David Herrington, 'Eliminating the Improbable: Sherlock Holmes and Standards of Evidence in the Genomic Age' Circulation 112.4 (2005) 2081-84; Howard L. Geyer, David M. Kaufman, Raminder K. Parihar, and Mark F. Mehler, 'Movement Disorders in COVID-19: Whither Art Thou?' Tremor and Other Hyperkinetic Movements 10.25 (2020) 1-4; X. Bai, J. Hippensteel, A. Leavitt, J. Maloney, D. Beckham, C. Garcia, Q. Li, B. Freed, D. Ordway, R. Sandhaus, E. Chan, 'Hypothesis: Alpha-1-Antitrypsin is a 
four-page article about clinical decision making. ${ }^{12}$ Others, however, are more cautious about perpetuating the myth of the Holmesian method. In 2018, Dr Thomas Young wrote a book warning of the dangers of the myth of Sherlock Holmes in forensic science, which had led, he contends, to the incarceration of innocent people. ${ }^{13}$ Young takes the classic example from A Study in Scarlet when Holmes meets Watson for the first time and effortlessly (but unconvincingly) gleans his profession, military association, and travel history from his tan, haggard face, and injured shoulder. As Young points out, this is not a good methodology because if we 'reason backwards' like Holmes, there is more than one train of events that might have got us here. Instead, he advocates using witness testimony (in this case Watson) to corroborate the evidence. As he notes: 'You can listen to an eyewitness with an open mind and see if what he says fits the clues, but you cannot make up a story from the clues and expect it to be true'. ${ }^{14}$

Nevertheless, Holmes's famous backwards reasoning commands an 'aura of plausibility', even 'an aura of generalised authority' that appeals to forensic scientists and physicians as much as to readers of fiction. ${ }^{15}$ And therein lies the problem with the myth of Holmes: his formidable rhetorical power outstrips the utility of his methods - a mismatch that provides a limit case for the public understanding of science more generally. It is partly for this reason that I am choosing to focus on Holmes, even though my doing so perpetuates what Anne Humphreys characterised in 1996 as the 'obsessive return of critical analysis' to Conan Doyle in studies of detective fiction. In her 2014 book, Late Victorian Crime Fiction in the Shadows of Sherlock, Clare Clarke argues that the nascent genre's capacity for narrative and moral complexity is still frequently overlooked in favour of a focus on Holmesian detection. Nonetheless, she concedes that late

Promising Treatment Option for COVID-19' Medical Hypotheses, 12 November 2020, https://doi.org/https://doi.org/10.1016/j.mehy.2020.110394.

${ }^{12}$ Michael Trimble and Paul Hamilton, 'The Thinking Doctor: Clinical Decision Making in Contemporary Medicine’ Clinical Medicine 16.4 (August 2016) 343-46.

${ }^{13}$ See: Thomas Young, The Sherlock Effect: How Forensic Doctors and Investigators Disastrously Reason Like the Great Detective (Boca Raton: Taylor and Francis, 2018).

${ }^{14}$ Young, The Sherlock Effect, p. 6.

${ }^{15}$ Young, 'Is Sherlock Holmes' "reasoning backwards" a reliable method for discovering truth? Analyses of four medicolegal cases' Heartland Forensic Pathology, LLC http://www. heartlandforensic.com/writing/is-sherlock-holmes-reasoning-backwards-a-reliablemethod-for-discovering-truth [accessed 24 November 2020]; David Levine, 'Revalidating Sherlock Holmes for a Role in Medical Education' Clinical Medicine 12.2 (2012) 164-69 (p. 164). 
nineteenth-century detective fiction did elicit a new kind of hero, of which Holmes is a prominent archetype. This archetype drew from and simultaneously reinforced a range of concerns about the changing relationship between science and society. Michael Saler identifies such fictions as part of a 'New Romance' genre which 'enchants and disenchants simultaneously' by rendering the imagination compatible with reason and combining 'the marvellous with the rational'. ${ }^{16}$ What makes Holmes distinct from contemporaneous fictional detectives is his cult status as 'larger than life'. Conan Doyle received letters addressed to Holmes requesting his consultation and advice. Some of these writers were what Saler terms 'naïve believers' and others 'ironic believers'-those who simply chose to suspend their disbelief. In the context of a nascent celebrity culture, some readers thought that Conan Doyle was Sherlock Holmes's literary agent, others thought he was Holmes. To complicate matters, Conan Doyle himself attempted to solve some much-publicised criminal cases. Magazines and newspapers published interviews 'with Holmes', as well as biographies of the famous detective and, when Holmes was killed off in 1893, even obituaries. A contemporaneous writer for The Times characterised such texts as 'the free creations of a mythological fancy, rather like the Eastern legends of Alexander the Great'. ${ }^{17}$ Here, I explore the legacies of this mythological fantasy in the context of the science of empire.

The fact both Conan Doyle and Porter reach for the same organising form-the doctor/detective dyad-says much about their cultural moment. The decades spanning 1880 to 1930 produced a plethora of 'scientific' detectives in popular fiction, and a wealth of journalistic accounts of medicine that invoked the figure of the detective (often specifically Holmes) as a shorthand for scientific or clinical insight. It was also a moment-as Clare Clarke notes-in which 'internal conflicts contained by the concept of nation were externalised onto the larger field of the empire'. ${ }^{18}$ Anxieties about national identity in the wake of fluctuating support for and criticism of Britain's increasingly militarised imperial engagements were distilled into stories in which Britain's right to rule

\footnotetext{
${ }^{16}$ Michael Saler, As If: Modern Enchantment and the Literary Prehistory of Virtual Reality (Oxford: Oxford University Press, 2012) p. 12.

${ }^{17}$ Quoted in Michael Saler, “"Clap If You Believe in Sherlock Holmes”: Mass Culture and the Re-Enchantment of Modernity, c. 1890-c. 1940' The Historical Journal 46.3 (September 2003) 599-622 (p. 600).

${ }^{18}$ Clare Clarke, Late Victorian Crime Fiction in the Shadows of Sherlock (Basingstoke: Palgrave Macmillan, 2014) pp. 1-2.
} 
became bound up with a fantasy about scientific endeavour. As Will Tattersdill has shown, the 'material entanglements' of science fact and science fiction in popular magazines like The Strand, which burgeoned at the turn of the century, 'shored up the empire by presenting empirical discovery and imperial conquest as inseparable'. ${ }^{19}$

For Jon Thompson, the Holmes stories represent a 'myth of England' in which empire and empiricism are the dominant structuring ideologies. Indeed, Conan Doyle was an outspoken supporter of imperialism. He defended British military engagements in South Africa in a series of letters to national newspapers and to the British Medical Journal, as well as in his nonfiction books: The Great Boer War (1900) and The War in South Africa: Its Cause and Conduct (1902). These were informed by his experiences as a military doctor at the Langman Field Hospital in Bloemfontein. He was president of the imperialist youth movement, the Boys' Empire League and wrote many jingoistic stories published in children's story papers such as Union Jack and the Boy's Own Paper. He also, Thompson argues, 'ratified the principles and ideologies of an imperial, patriarchal Britain' through his fiction in ways that facilitated a popularisation of empiricism and of the scientific method. ${ }^{20}$

Laura Otis, Lorenzo Servitje, and Susan Cannon Harris, among others, have explored the collision of medicine and empire embodied by Conan Doyle's use of the language of epidemiology to symbolise 'the physical, moral, and cultural contamination that Britain feared as its empire brought it into closer contact with Asian and African peoples, cultures, and climates' ${ }^{21}$ Against this backdrop Holmes emerges as Britain's salvation; for Otis, Holmes acts as an imperial immune response, protecting the metropole from foreign bio-contaminants and '[bringing] to life the fantasy of a national immune system'. ${ }^{22}$ She reads the Holmes canon through this metaphor of imperial immunology - a figuration that Conan Doyle does not himself explicitly name but which helpfully encapsulates both the imperial and medical contexts of his writing, and the essence of Holmes's appeal for readers. 'The British loved Holmes', she argues, 'for the same

\footnotetext{
${ }^{19}$ Will Tattersdill, Science, Fiction, and the Fin-De-Siècle Periodical Press (Cambridge: Cambridge University Press, 2016), p. 140.

${ }^{20}$ Thompson, Fiction, Crime and Empire, pp. 74-76.

${ }^{21}$ Susan Cannon Harris, 'Pathological Possibilities: Contagion and Empire in Doyle's Sherlock Holmes Stories' Victorian Literature and Culture 31.2 (2003) 447-66 (p. 449).

${ }^{22}$ Laura Otis, Membranes: Metaphors of Invasion in Nineteenth-Century Literature, Science, and Politics (Baltimore: Johns Hopkins, 1999) p. 91.
} 
reason that fin-de-siècle Europeans admired scientists like Robert Koch and Louis Pasteur'. ${ }^{23}$ Like the tropical pathologist, Holmes was, for the reading public, 'an imperial knight who served the empire through his enhanced vision'. ${ }^{24}$ In his biography of Conan Doyle, published in 1943, British actor and writer (Edward) Hesketh Pearson similarly positioned Holmes as a defender of empire and a model for imperial masculinity: 'Sherlock Holmes is what every man desires to be; like Don Quixote, he is a knight-errant who rescues the unfortunate and fights single-handed against the powers of darkness'. ${ }^{25}$

Pearson's recourse to Don Quixote is revealing for a number of reasons, none of which were perhaps intended. Most obvious is that Miguel de Cervantes's fictional character is, as the Encyclopaedia Britannica notes, only a 'would-be knight errant' whose 'delusions of grandeur' lead to 'comic misadventures' in which he and companion Sancho Panza imagine the 'mundane world of the Spanish countryside as something more exciting and dangerous'. ${ }^{26}$ Pearson's comparison between Quixote and Holmes then would seem to undermine Holmes's fitness as a model for which to aspire. Indeed, the comparison's implicit suggestion that Holmes sees grandeur where there is none was also voiced by contemporary critics, who relentlessly satirised the detective's methodology. One critic wrote facetiously of Holmes that 'everything for him had a meaning, and what did not have a meaning had one promptly manufactured to fit into it'. ${ }^{27}$ Charles Hamilton (under the pen name Peter Todd) produced a whole series of parodies involving 'Herlock Sholmes' and 'Dr Jotson'. In 'The Case of the Biscuit-Tin!' Jotson is endlessly impressed by Sholmes's basic and obvious deductions about his morning routine:

"[First $]$ you rose from that bed."
I started.
"It is true," I admitted. "But how__

${ }^{23}$ Otis, 'The Empire Bites Back: Sherlock Holmes as an Imperial Immune System' Studies in 20th and 21st Century Literature, 22.1 (1 January 1998) p. 2.

${ }^{24}$ Otis, Membranes, p. 98. A cartoon depicting Koch in this way appeared in Germany's humourous magazine Ulk and was reprinted to accompany Conan Doyle's article on Koch for the Review of Reviews in 1890.

${ }^{25}$ Hesketh Pearson, Conan Doyle: His Life and Art (London: Methuen and Co., 1943) n.p.

26 'Don Quixote' Encyclopaedia Britannica (11 Jan. 2018) Online: https://www.britannica.com/topic/Don-Quixote-fictional-character [accessed 2 March 2021].

${ }^{27}$ A. Dewar Willock, 'A Study in Red' Fun (6 July 1892) n.p. 
"You then took your morning bath."

"Sholmes!"

"And you breakfasted upon eggs and bacon."

"Marvellous!"

$[\ldots]$

"Nothing at all, my dear boy. Deduction, that's all."

"But how__ "

$[\ldots]$

"In the first place, you are now in a perpendicular attitude."

"True!"

"The observations of a lifetime have led me to conclude that in bed people generally — in fact, almost invariably — assume a horizontal attitude."

"True again!" I exclaimed. "I had not observed it, but, now that you point it out, I must admit that so far your deductions seem very simple."

$[\ldots]$

"Your present perpendicular attitude shows indubitably that you rose from your bed. As for your bath, I have observed your customs during the time we have been together at Shaker Street.”

$$
[\ldots]
$$

"Perfectly correct. But the eggs and bacon?"

$[\ldots]$ "Upon your moustache remains a slight trace of the breakfast egg [...] Bacon and eggs frequently - in fact, almost invariably - are taken together. From the eggs I deduced the bacon."

"Marvellous!" 28

Sherlock Holmes parodies were only possible because he was a household name, his methodologies familiar territory for readers. As Saler intimates, he represented a departure in fiction, becoming an intermediary figure between the real and the imagined that had much in common with the 'more ambiguous ontological status' of mythological and legendary characters. ${ }^{29}$ Many believed that Holmes was real, or else happily suspended their disbelief so that they might inhabit a world wherein such people existed, a phenomenon made more complex by Holmes's prevalence as a model for the practices of experimental and diagnostic medicine. Pearson's comparison then brings us back to the mythological self-fashioning of parasitologists that I explored in my first chapter.

${ }^{28}$ Peter Todd, 'The Case of the Biscuit-Tin!' The Greyfriar's Herald (27 November 1915) 3-5 (p. 3).

${ }^{29}$ Saler, As If, p. 6. 
The 'knight of science' and the scientific detective were kindred fantasies often made interchangeable in the popular imagination. In 1922, The Times, for example, eulogised tropical medicine giant Patrick Manson as a 'builder of the British Empire' framing both Manson and the birth of the discipline using detective fiction's most famous archetype; the article located the 'hour in which tropical medicine was to be born' as the hour in which Manson put together his evidence for the mosquito vector of elephantiasis, 'like Sherlock Holmes' ${ }^{30}$ Here detective fiction becomes a mode in which to understand the work of parasitologists. Drawing on a long-standing conceptual and rhetorical association between crime and disease, journalists and biographers framed parasitologists as sleuths solving impossible puzzles and tracking down microbe and insect 'murderers'. The News of the World dubbed Ross's malaria research as 'one of the greatest detective stories of modern times', whilst elsewhere he was described as 'the man who tracked down the malaria germ' and apprehended the 'criminal mosquito'. ${ }^{31}$ Parasitologist David Bruce was similarly eulogised as the 'Sherlock Holmes of science' in 1931. ${ }^{32}$

By using this shorthand, writers invoked not the realities of experimental science, but a fantasy about modern, western, Anglophone objectivity that continues to augment instrumental relationships between science and society. As Otis argues, Conan Doyle's creation of 'a hero with penetrating vision' was a narrative realisation of a contemporary medical fantasy: the ability to perceive the imperceptible. ${ }^{33}$ In this chapter, I bring the context of empire to bear on the concept of medical detection by placing the formal strategies of detective fiction in dialogue with the representational strategies of parasitology. By framing microbes as murderers and doctors as detectives, fictional and nonfictional writers alike invoked the confidence of domestic legal authority to control and order the chaotic phenomenon of tropical illness. In doing so, I argue, they supported a slippage between crime and disease that bolstered the biopolitical authority of

\footnotetext{
${ }^{30}$ London, LSHTM. RC. GB 0809 Ross/138/02-03. 'Pioneer of Tropical Medicine. Sir P. Manson's Great Work. An Empire Builder'. The Times, 10 April 1922. n.p.

${ }^{31}$ London, LSHTM. RC. GB 0809 Ross/156/153. [no title], News of the World. 23 Oct 1921, n.p.; London, LSHTM. RC. GB 0809 Ross/156/119-159. 'The Man Who Tracked Down the Malaria Germ' John O’ London's Weekly, 21 May 1921, n.p.

32 'Funeral of Sir David Bruce', The Scotsman, Wednesday 2 December 1931, p. 12; 'Sir David Bruce Dead', The Scotsman, Saturday 28 November 1931, p. 10.

${ }^{33}$ Otis, Membranes, pp. 90-118 (p. 94).
} 
Western medicine-an authority explicitly grounded in British imperial politics.

\section{Heroes of Real Life: Medicine and Empire}

Nils Clausson contends that when Sherlock Holmes was introduced to the world in A Study in Scarlet in 1887, the 'myth of the scientific detective was born'. Critics, he asserts, have since that moment largely taken Watson's contention that Holmes has 'brought detection as near an exact science as it will ever be brought' at face value. Despite the orthodox view of Holmes as, in Jon Thompson's words, the 'quintessential empiricist', or, in Catherine Belsey's, a figure who demonstrates the 'comprehensive power of positivist science', Clausson argues that there is in fact a remarkable lack of applied science in the Holmes canon. ${ }^{34} \mathrm{He}$ is not alone in this observation. Notwithstanding James O'Brien's assertion in The Scientific Sherlock Holmes (2013) that science makes an appearance in 'every one of the sixty stories [and] in some stories, science is the dominant factor', scholars have drawn attention to the numerous occasions in which Holmes fails to properly employ his fabled empirical methodology, tantalises us with science that does not then have any bearing on the resolution of the plot, or dispenses with empiricism all together. Holmes frequently admonishes Watson in one moment: 'It is a capital mistake to theorise before you have all the evidence. It biases the judgement', and engages in the forbidden behaviour in another. ${ }^{35}$ Just a few pages after the aforementioned remark in A Study in Scarlet, and after only a preliminary examination of evidence at the crime scene, Holmes admits that 'as a matter of fact, my mind is entirely made up on the case, but still we may as well learn all that is to be learned' (33). And yet, despite these inconsistencies, Holmes continues to be renowned for his unparalleled scientific logic in scholarly criticism, medical commentary, and popular culture. What is interesting then is not whether or not Holmes truly is the 'quintessential empiricist' but the astonishing staying power of this particular kind of fantasy.

Ronald R. Thomas identifies not scientific objectivity but escapism as the driving force behind the Holmes canon, arguing that Watson's 'overly

${ }^{34}$ Nils Clausson, 'Degeneration, "Fin de Siècle" Gothic, and the Science of Detection: Arthur Conan Doyle's "The Hound of the Baskervilles" and the Emergence of the Modern Detective Story' Journal of Narrative Theory 35.1 (Winter 2005) 60-87 (p. 60).

${ }^{35}$ Conan Doyle, A Study in Scarlet, p. 27. 
romantic literary accounts' of Holmes's cases (for which he is often reproved) and Holmes's addiction to narcotics are cut from the same cloth as his imagined profession. They embody a desire to 'escape from the peculiar historical circumstances in which [Holmes and Watson] live' and to embark on 'quests for some elusive truth'. ${ }^{36}$ These peculiar historical circumstances include the anxious politics of empire famously embodied by Watson's return as a wounded soldier from Afghanistan to join the other 'loungers and idlers of the Empire' who are 'irresistibly drained' into the 'cesspool' of London. ${ }^{37}$ With a shattered collar bone and convalescing from enteric fever- 'that curse of our Indian possessions'-Watson voices the fear that British men might be 'irretrievably ruined' by their engagements with empire.

The context of empire asserts itself in the margins-margins of plot: there are references to malaria, yellow fever, and enteric fever in at least five stories, and many more that include persons and artefacts from the colonies; and margins of form: Thomas reminds us of the dialogic format of popular magazines where

articles $[\ldots]$ on a new medical invention that could diagnose criminal pathologies might appear [...] inserted between a Sherlock Holmes mystery about an aboriginal savage criminal from India and a regular feature on "News from the Empire" that offered thrilling accounts of British military heroism in the colonies. ${ }^{38}$

This is something that Will Tattersdill has elsewhere described as the 'material entanglements' of 'Standard Popular Illustrated Magazines', which allow literature and science to become 'active agents within popular culture'. ${ }^{39}$

Despite Clare Clarke's contention that detective fiction, including the Holmes canon, is an 'ideologically complicated' body of work, and despite Stephen Arata's assertion that in his fiction Conan Doyle cannot seem to 'prevent even his staunchest defences [of Empire] from being hounded by doubt', audiences insisted - and continue to insist-on reading Holmes as a counterpart to those 'thrilling accounts of British military heroism in the

\footnotetext{
${ }^{36}$ Ronald R. Thomas, Detective Fiction and the Rise of Forensic Science (Cambridge: Cambridge University Press, 1999) p. 2.

${ }^{37}$ Conan Doyle, A Study in Scarlet, p. 14.

${ }^{38}$ Thomas, Detective Fiction and the Rise of Forensic Science, p. 5.

${ }^{39}$ Tattersdill, Science, Fiction, and the Fin-De-Siècle Periodical Press, p. 4.
} 
colonies'. ${ }^{40}$ Although undoubtedly reductive and essentialist, the persistence of Holmes as a 'new kind of hero' in the popular imagination-as, in Conan Doyle's words, 'a benefactor of the race'-owes much to the contexts of medicine and empire within which the stories were written and originally read. As I argue further, the scientific detective both reinforced-and was reinforced by - a popular understanding of science as a modern form of romance.

Caroline Reitz claims that 'nineteenth-century detective fiction helped a national readership imagine the British Empire in a way that was at once destabilising and reassuring' ${ }^{41}$ Empire in these fictions offers mystery and adventure but also danger and peril. She reads Sherlock Holmes in the context of a historical moment that also produced Rudyard Kipling's Detective Strickland. In doing so, she draws our attention to the formal similarities between English crime fiction and imperial adventure fiction, genres that are often simultaneously concerned with a fantasy of surveillance and the ideology of empire (65-66). Arata also reads Holmes in the context of fictions of empire, arguing that the stories are indebted to the genre of male romance. The romance genre, 'like late-Victorian imperialist ideology generally', he argues, 'is centrally concerned with the possibility of renewal'. It provided 'a stage on which fantasies of a revitalised masculinity [were] played out', where the perceived moral and physical decline of England might be reversed through a commitment to the masculine pursuits of empire. ${ }^{42}$ For Holmes and Watson, the masculine pursuits of empire play out in the 'exotic locale' of the criminal underworld where the 'Great Game' is transferred from a physical to an intellectual register and where they triumph as 'domestic versions of the romance form's stereotypical men of action'. ${ }^{43}$

Many scholars have unwittingly adopted the Victorian fantasy of a metropole-periphery divide when analysing these genres, Reitz argues, and so they taxonomise Conan Doyle as a writer of detective stories and Kipling as a writer of imperial intrigue. However, there is more to connect these genres than divide them. She identifies significant continuities, for

\footnotetext{
${ }^{40}$ Clare Clarke, Late Victorian Crime Fiction in the Shadows of Sherlock, p. 2; Stephen Arata, Fictions of Loss, p. 139.

${ }^{41}$ Caroline Reitz, Detecting the Nation: Fictions of Detection and the Imperial Venture (Columbus: The Ohio State University Press, 2004) p. xiii.

${ }^{42}$ Stephen Arata, Fictions of Loss in the Victorian Fin de Siècle: Identity and Empire (Cambridge: Cambridge University Press, 1996) pp. 79-80.

${ }^{43}$ Arata, Fictions of Loss, p. 147.
} 
example, between 'the detective who treats crime and the explorer who performs the work of imperial administration'. For Reitz, the modern detective is uniquely suited to 'maintaining social order in a complex new imperial world $[\ldots]$ because his authority stem[s] from knowledge rather than force and because his knowledge promise[s] mastery of a specifically imperial world'. ${ }^{44}$ The weaponisation of specialist knowledge in the service of empire also makes the detective a fitting analogue for the parasitologist or tropical pathologist, whose work, as I explored in the previous chapter, was likewise informed by the structures and fantasies of the male romance genre.

As Laura Otis argues in Membranes (1999), microbiologists garnered considerable popularity in this period as 'imperial knights' or 'heroes' of science, bolstered by imperialistic and sensationalised popular accounts of their research in newspapers and magazines. Conan Doyle was himself influenced by the sensation around German bacteriologist Robert Koch, who he travelled to Berlin to witness demonstrate a cure for tuberculosis in 1890. Otis identifies this as an influential moment in his career. Kathleen E. Hames also identifies the 'Berlin episode' as a key moment for Conan Doyle, arguing that his trip to see Koch precipitated a 'decisive shift [which led] him to abandon his medical practice to pursue literature full time'. ${ }^{45}$ It is curious that this significant bacteriological moment led ultimately to a consolidation of his interest in literature, not in medical research. Despite both scholars insisting on the significance of the trip, it reads as a somewhat underwhelming event in his autobiography (serialised in The Strand and published as a book in 1924). And as Otis notes, Conan Doyle never got to meet Koch in the end or even witness the 'cure' being demonstrated by Dr Bergmann. He did get to visit some of Koch's patients and read the lecture notes of one of the attendees; however, in his autobiography, he writes: 'I had the temerity to disagree with every [case] and to come to the conclusion that the whole thing was experimental and premature'. ${ }^{46}$

This sober appraisal sits uneasily with the article he wrote for Review of Reviews in which he describes Koch as a 'great mastermind [...] bringing under subjugation those unruly tribes of deadly micro-organisms which

${ }^{44}$ Caroline Reitz, Detecting the Nation, p. xiv.

${ }^{45}$ Kathleen E. Hames, Imperial Fever p. 54.

${ }^{46}$ A. Conan Doyle, 'Memories and Adventures-Chapter VIII. Pulling Up the Anchor' The Strand Magazine 67.397 (January 1924) 85-87 (p. 85). 
are the last creatures in the organic world to submit to the sway of man'. ${ }^{47}$ From these imperialistic words, we see that Conan Doyle came back from Berlin, not with a passion for medicine so much as a passion for the narrative romance of medicine. Indeed, the 'romance of medicine' forms the subject and title to a speech that he gave to medical students at St Mary's Hospital in 1910. 'In every literary or dramatic romance', he asserted, once the 'villain was unmasked he was innocuous. It was the undiscovered villain who was formidable'. He goes on to characterise the recent work in the 'wonderful romance of medicine' in terms of exposing 'the villain', referring to the mosquito and rat-flea as 'accomplices'. This is an explicitly British romance, which his fellow countrymen could take 'peculiar satisfaction' in as 'protagonists in the battle'. As The Times reported for a popular audience, for Conan Doyle, 'the great line which honoured British medicine since the days of Harvey had never had a more brilliant group than that which contained the names of Manson, Ross, Bruce, and Wright'. ${ }^{48}$

In letter correspondence with Lady Cowan, wife of liberal MP Sir William Henry Cowan, Conan Doyle again revealed his admiration of the work of parasitologists, asserting: 'Sir Ronald Ross has always been one of my heroes of real life. If honours went by achievement he should surely be a Duke'. ${ }^{49}$ The two men went on to become firm friends and in 1928 Conan Doyle wrote to the Daily Express to suggest that Ross should be made a member of the House of Lords, styling him 'the most successful of all Generals winning victory for the human race against the Malaria Fiend which has claimed its victims by the million' ${ }^{50}$ Using the naturalised metaphor of medicine as war, Conan Doyle suggests that Ross has earned the political and social power reserved for the English nobility.

Whilst many of the Holmes stories clearly predate the discoveries made by Ross and his colleagues, Conan Doyle and Ross share a kindred fantasy about the power of the specialist to neutralise threats to the individual, and by extension, the nation. His characterisation of Ross as a general 'winning victory for the human race' suggests that he, like Ross, thought

\footnotetext{
${ }^{47}$ Arthur Conan Doyle, 'Dr Koch and his Cure' Review of Reviews 1 (1890) 552-56 (p. 552).

48 'The Medical Session: St Mary's Hospital' The Times, 4 October 1910, p. 7.

${ }^{49}$ London, LSHTM. RC. GB 0809 Ross/146/16/69. Doyle to Lady Cowan. January 1914.

50 'Fashionable and Personal' Kent \& Sussex Courier, Friday 12 October 1928, p. 8.
} 
of medicine as 'an imperialistic battle fought on the home front'. ${ }^{51}$ Indeed, Conan Doyle used medico-military analogies to this end in The Narrative of John Smith - a semi-autobiographical novel that was ostensibly written in 1883 , lost in the mail on its way to the publisher, and rewritten from memory several years later. He never finished rewriting the narrative and it remained unpublished until 2010 when it was published by The British Library.

The story is told through a series of conversations and soliloquies involving John Smith, a bedridden man recovering from rheumatic gout. As the nascent voice of Conan-Doyle-as-author, the Narrative brings into clear focus many of the ideologies that would come to underpin his later writing: his ambivalence about the colonial encounter, his anxieties about the health of the British, and his idealisation of medical science and adulation of its researchers. In chapter two, Dr Turner explains the power and potential of scientific research:

'Typhus, typhoid, cholera, malaria, hydrophobia, scarlatina, diphtheria, measles and probably consumption will cease to exist-and all owing to the labours of Louis Pasteur-God bless him!'

'Why, Doctor,' said I, 'you are quite an enthusiast.'

'Yes,' he answered, mopping his flushed face. 'It's a subject which warms my very heart. We are at war with these pestilential atoms and when we gain a victory over them the whole human race should light up their candles and sing "Te Deum." 52

In the final chapter of the unfinished manuscript, Conan Doyle again invokes warfare as a frame of reference for understanding the maintenance of health:

'How preposterous it seems,' I remarked. 'We are like some defenceless country with open frontiers, exposed to the invasion of every wild tribe of microbes who choose to attack us.'

'Very true. But you have an admirably drilled standing army for your defence.'

${ }^{51}$ Otis, 'The Empire Bites Back', p. 33.

${ }^{52}$ Arthur Conan Doyle, 'The Narrative of John Smith' The Arthur Conan Doyle Encyclopaedia (2020) https://www.arthur-conan-doyle.com/index.php/The_Narrative_ of_John_Smith [accessed 18 January 2021] (Ch. 2). 
'In my case, then,' said I, 'the standing army appears to have been defeated, and I am falling back upon my auxiliary forces.'

'Not at all. It has been a contest of six days, but your guards have been victorious. You have read, I presume, the recent investigations on the subject of the functions of the leucocytes [...] They outdo the wildest dreams of Romance. You know what a leucocyte is? They are little microscopic jellylike creatures which are found drifting along in our bloodstream [...] recent experiment[s have shown] that these creatures are the most trusty and energetic friends of the human race-the special bodyguards and household troops which garrison his system.'

This conceptualisation of the immune response was continuous with dominant analogies that became idiomatic following the development of immunology. In 1883, Russian embryologist Elias Metchnikoff had put forward his theory of phagocytosis wherein certain cells of the body, which he termed phagocytes, actively worked to preserve host integrity by engulfing and digesting, not just nutrients, but also foreign pathogenic material. As Edith J. Claypole summarised for readers of The American Naturalist in 1894, white blood cells 'form, as it were, a guardian army in the animal body, ever alert and watchful for the invading enemy. A constant warfare is being waged between these leucocytes and all foreign material' (316).

The use of such medico-military language long predates the popular acceptance of germ theory, as Lorenzo Servitje has recently investigated. Servitje grounds martial figurations of disease in the material intersection of medicine and the military at the turn of the eighteenth into the nineteenth century. From the impact of military campaigns on the spread of epidemics, to public health measures based on the model of cordon sanitaire, to the discursive construction of miasma as an 'inimical enemy' and cholera as a marching army, the conceptual space between military and medical intervention was frequently elided. Moreover, debates concerning disease aetiologies and transmission were often staged in the context of military and colonial practices. ${ }^{53}$

Nevertheless, as Servitje contends, war, microbiology, and immunology further converged in the 1880s following the work of Metchnikoff and others (189-90). Leon Chernyak and Alfred Tauber argue that although he was not the first to claim a theory of immunity, Metchnikoff was

${ }^{53}$ Lorenzo Servitje, Medicine is War: The Martial Metaphor in Victorian Literature and Culture (Albany: SUNY Press, 2021) see in particular: pp. 41-64. 
influential because he radically reimagined the host's maintenance of its own bodily integrity. ${ }^{54}$ Phagocytosis reconceptualised immunity as an active defence rather than a passive resistance and in doing so precipitated a conceptual shift in which the rhetorical battlefield was translocated from the political terrain of international and interpersonal encounters in the world, to the microbiological terrain of intracellular encounters in the body. The use of the martial metaphor in this way was widespread, from William Osler's characterisation of phagocytosis as 'active destructive warfare' in 1889 to the translator's choice to describe the interactions between phagocytes and parasites as a 'battle' in the English edition of Julius Mannaberg's 'The Malarial Parasites' in $1894 .{ }^{55}$

The doctor's insistence in the Narrative that leucocytes 'outdo the wildest dreams of Romance' signals again Conan Doyle's investment in not only military metaphors but also the adventure mode. He writes, ' $[\mathrm{T}]$ he most bloodthirsty tiger that ever trod a jungle is harmless compared to these microscopic spores and filaments', and refers to 'Koch's bacillus of phthisis and the comma-shaped bacterium of cholera' as 'little villains'. Thus, the Narrative contains the germs - if we can excuse the pun-of later franchises such as the expeditions of Professor Challenger and the criminal investigations of Sherlock Holmes. Indeed, the parallels between the microscopic and macroscopic gestured to here are invoked in reverse when we meet fictional microbiologist Henry Tarp in The Lost World. Tarp 'live[s] in a nine-hundred-diameter microscope' and is a 'frontiersman at the extreme edge of the knowable'. ${ }^{56}$ Although this 1912 story concerns formidable creatures of a much larger size, readers might have gleaned an insight into the kind of adventures that populated Tarp's microscopic vision by an early nonfiction piece published by Conan Doyle in Good Words four years before he wrote his first Holmes story. In 'Life and Death in the Blood' (1883), Conan Doyle invites his readers to imagine shrinking down to microscopic size to travel through the arteries of the body. Using the tropes of imperialist adventure, he promises to tell us

\footnotetext{
${ }^{54}$ Leon Chernyak and Alfred I. Tauber, 'The Idea of Immunity: Metchnikoff's Metaphysics and Science' Journal of the History of Biology 23.2 (1990) 187-249.

${ }^{55}$ William Osler, 'Phagocytes and Parasites' British Medical Journal 1.1479 (1889) p. 1012; Julius Mannaberg, 'The Malarial Parasites: A Description Based Upon Observations Made by the Author and by Other Observers' trans. by R. W. Felkin in Two Monographs on Malaria and the Parasites of Malarial Fevers (London: The New Sydenham Society, 1894) p. 400.

${ }^{56}$ Arthur Conan Doyle, The Lost World (1912; London: The Folio Society, 2010) p. 17.
} 
of 'work which has opened up a romance world of living creatures', which he compares to 'venomous cobras' and 'savage tigers' and, perhaps most tellingly of all, refers to as a 'race' of organisms living in the blood. The phrasing recalls John Smith's conceptualisation of disease as caused by 'wild tribes' of microbes. Implicit in such figurative language is the idea that the 'tropical' and 'microscopic' are kindred realms.

Conan Doyle again invoked the tropical world as a frame of reference for understanding the destruction wrought by microorganisms in his article about Koch's cure for tuberculosis published in Review of Reviews in 1890:

It is a strange thing to look upon these utterly insignificant creatures, and to realize that in one year they would claim more victims from the human race than all the tigers who have ever trod a jungle. A satire, indeed, it is upon the majesty of man when we look at these infinitesimal and contemptible creatures which have it in their power to overthrow the strongest intellect and to shatter the most robust frame. ${ }^{57}$

By juxtaposing microbes in the blood with tigers and cobras in the jungle - a strategy he repeats in 'Life and Death in the Blood' and the Narrative - Conan Doyle opens up imaginative space for a new kind of colonial encounter. In 1925, parasitologist and director of the London School of Tropical Medicine Andrew Balfour employed a similar rhetorical technique when speaking about the impact of malaria on the British Empire. In an address delivered at the Guild House, Eccleston Square, he asserted that if malaria 'fastens' upon the Indian native, 'he has little more chance than if he were in the claws of a Bengal tiger'. ${ }^{58}$

Conan Doyle's anxiety about the infinitesimal in 'Life and Death in the Blood' is matched only by his confidence in the 'gigantic intellect' of specialists like Koch and Pasteur. Throughout he writes repeatedly of 'great minds', 'gigantic intellect[s]', 'rare scientific intuition', 'master minds of the century', 'active brain[s]', 'great thinker[s]', and 'savants'. Thus, he produces a binary narrative of microscopic threat versus scientific brilliance that is also modelled in many of the Holmes stories. Indeed, many scholars have argued that Holmes's emphasis on the importance of 'small

\footnotetext{
${ }^{57}$ Arthur Conan Doyle, 'Dr Koch and His Cure' Review of Reviews 2.12 (December 1890) 552-60 (p. 552).

${ }^{58}$ Andrew Balfour, 'Malaria as an Enemy of the British Empire', p. 6 [MS of address delivered 18 October 1925] London, LSHTM. GB 0809 Balfour/01/07.
} 
trifles' parallels the microscopic vision of microbiologists. As Servitje puts it: 'microbial and immunological metaphors thematically and narratively govern' the Holmes stories. ${ }^{59}$ This is, moreover, not simply a loose symbolic parallel but a conceptual exchange that was given cultural currency in journalism, biography, and popular medicine.

Just three years after his discovery and two years before he would win the Nobel Prize, London evening newspaper the St James's Gazette described the crescendo of Ross's mosquito-malaria work by drawing just this parallel. 'At last' they wrote, 'he traced his parasite as Sherlock Holmes might track a criminal'. ${ }^{60}$ Manson was similarly compared to the great detective, and upon the death of parasitologist David Bruce, several newspapers asserted that he was known as 'the Sherlock Holmes of science'. ${ }^{61}$ By invoking the romance of detective fiction and the eponymous detective as a reference point, journalists popularised an idealisation of the scientific method where talented individuals carried out research that was tantamount to bringing criminals to justice. Throughout the early twentieth century, the detective became a powerful and convenient trope for demonstrating the social value of doctors and medical researchers. 'A large portion of the modern doctor's activities is devoted to what can only be described as detective work of a very high order', asserted Adelaide's daily colonial newspaper The Advertiser:

Whether it be the tracing of some mysterious disease to its hidden cause, or the tracking through various intricate channels of a promising but elusive method of cure, the medical man is frequently compelled to adopt the principles and practices of Sherlock Holmes. ${ }^{62}$

${ }^{59}$ Servitje, Medicine is War, p. 208.

${ }^{60}$ 'Mosques and Mosquitoes' St James's Gazette, Monday 12 November 1900, p. 12.

${ }^{61}$ See for example: 'Funeral of Sir David Bruce' The Scotsman, Wednesday 2 December 1931, p. 12; 'Sir David Bruce Dead' The Scotsman, Saturday 28 November 1931, p. 10; 'The Sherlock Holmes of Science' Nottingham Evening Post, Friday 27 November 1931, p. 6; 'Sir D. Bruce Dead. Sherlock Holmes of Science. Found Fever Germ' Liverpool Echo, Friday 27 November 1931, p. 7; 'Sir David Bruce Dies During Wife's Funeral Service. Adventures of "The Sherlock Holmes of Science"' Daily Mirror, Saturday 28 November 1931, p. 6; 'Sir David Bruce Dead. Great Discoveries in the Realm of Tropical Medicine' Coventry Evening Telegraph, Friday 27 November 1931, p. 10.

62 'Doctors as Detectives. Tracking the Causes of Deadly Diseases' The Advertiser, Friday 2 March 1923, p. 17. 
A correspondent for the Daily Herald likewise asserted, under the emotive title 'A Romance of Science', that upon reading Ross's Memoirs 'one realises how much more thrilling are the exploits of the detective of science- the hero of fact - than those of the detective of crime- the hero of fiction'. ${ }^{63}$

\section{Medical Detectives and 20-20 Vision}

In John Rowland's book The Mosquito Man, he describes the 'sensation' caused at the British Medical Association when Manson read out a telegram from Ross reporting his discovery: 'it was rather like the sensation that might be expected if a great detective at Scotland Yard announced the arrest of a criminal at the end of a long and difficult case' ${ }^{64}$ Declaring that Ross's research was 'not unlike a detective story', he asserts that 'the clues were very difficult to find and when found very difficult to interpret' (90). This encapsulates the imagined confluences between the skill set of the idealised pathologist and of the idealised detective, both credited with the possession of a special type of vision that allows them to make deductions others cannot. In his autobiography, Italian parasitologist Aldo Castellani describes a scene in which his mentor, Patrick Manson, diagnosed a rare disease by virtue of this special vision. According to Castellani, a patient suffering from a skin disease coughed up 'a huge gelatinous glob' onto Manson's prized Bokhara carpet and in his inspection of the spoiled material Manson noticed some minute rusty spots in the mucous. He rushed to his microscope and discovered 'peculiar large ovoid bodies' which he immediately recognised as the eggs of a worm, paragonimus.

Castellani breezes over any experimental proof or subsequent research in order to declare that Manson had-in that moment- 'discovered the cause of endemic haemoptysis, a common and grave disease simulating phthysis $[$ sic $]$ in the Far East'. ${ }^{65}$ Likewise, Castellani narrates the moment he first laid eyes on the trypanosome parasite in the cerebrospinal fluid of a patient as the moment that he discovered that it was the causative agent of sleeping sickness. The discovery was later attributed to David Bruce

63 'A Romance of Science' Daily Herald, Thursday 28 June 1923, p. 4.

${ }^{64}$ John Rowland, The Mosquito Man. The Story of Sir Ronald Ross (London: Lutterworth Press, 1958) p. 130.

${ }^{65}$ Aldo Castellani, Microbes, Men, and Monarchs. A Doctor's Life in Many Lands (London: Richard Clay and Company, 1960) p. 28. 
who joined the sleeping sickness expedition after Castellani and continued his work. The question of priority subsequently occupied the medical and national presses, just as Ross's bitter public dispute with Italian investigator Giovanni Battista Grassi had done. ${ }^{66}$ Here and in many medical biographies and travelogues, sight is privileged as a tool of scientific discovery. The act of seeing is made synonymous with the material practices of experimental medicine-a dynamic that found embodiment in Holmes's powerful diagnostic gaze.

And yet, as William Bynum has argued 'seeing microscopically was something that had to be learned, and there was much disagreement about what was seen, to say nothing of the significance of the images the microscope revealed'. ${ }^{67}$ Although Ross would eventually prove that mosquitoes transmitted the parasite responsible for malaria via their bites in 1897, just a few years earlier he had been vehemently against the idea that malaria was caused by a parasite at all. In 1889, he wrote four papers hypothesising that malaria was due to intestinal poisoning, and in 1892, four more papers denying the existence of Laveran's malaria parasite altogether.

In 1880, French doctor Alphonse Laveran had discovered microscopic bodies containing black pigment in the blood of patients suffering from malaria, which he believed to be protozoan parasites responsible for causing the disease. Whilst some supported Laveran's findings, many did not, and the identification of a bacillus supposedly responsible for malaria in the pontine marshes by Corrado Tommasi-Crudeli and Edwin Klebs the previous year threw Laveran's claims into further doubt. Ross believed, like many others, that Laveran's 'parasite' was in reality a degenerated red blood cell or the nuclei of a leucocyte, or some other microscopy viewing error. He doubted its connection to malaria, citing the plethora of microorganisms found in the blood and in drinking water as a reality that precluded the case for any one microorganism over another. Mary Kingsley humorously outlined the confusion over the causative agent of malaria in her Travels in West Africa (1897) when she asserted: "when the peculiar microbes of everything from measles to miracles were being "isolated",

\footnotetext{
${ }^{66}$ Castellani, p. 50. Also see: Emilie Taylor-Brown, "Petty Larceny" and "Manufactured Science": Nineteenth-Century Parasitology and the Politics of Replication' in Replication in the Long Nineteenth Century: Re-makings and Reproductions ed. by Julie Codell and Linda K. Hughes (Edinburgh: Edinburgh University Press, 2018) pp. 67-83.

${ }^{67}$ W. F. Bynum, Science and the Practice of Medicine in the Nineteenth Century (Cambridge: Cambridge University Press, 1994) p. 101.
} 
several bacteriologists isolated the malarial microbe, only unfortunately they did not all isolate the same one'. ${ }^{68}$

By 1895, however, Ross had changed allegiances, describing the parasite's life cycle for readers of The Spectator and insisting that its presence in the blood as a cause of malaria was 'now an old tale, known for about fifteen years'. ${ }^{69}$ This radical change in stance was partly a product of his improved microscopy training-in his Memoirs, he attributes his interpretative errors to his former microscope technique being 'too beautiful and complicated'.${ }^{70}$ But it was also a product of his newfound friendships with Laveran and Manson, and a willingness to 'see' the parasite within new frames of reference. ${ }^{71}$ In Vision, Science, and Literature, Martin Willis draws our attention to the 'historical fragility' of vision. He examines how 'instruments, objects, people, eyes, ideologies, discourses, and imaginations together ma[de] the many ways of seeing that characterise[d] the second half of the nineteenth century and the opening decades of the twentieth'. In this period, vision came to be experienced as a 'negotiation between the actual and the metaphoric, the real and the imagined' ${ }^{72}$ This is aptly illustrated by a heated debate between Ross and fellow Indian Medical Service officer, Edwin Lawrie, which was covered by The Times, the British Medical Journal, the Indian Lancet, and English-language Indian newspaper The Pioneer in 1897. Lawrie contended that Laveran's malaria parasite did not exist, describing Laveran's diagrams as 'fanciful pictures $[\ldots]$ drawn from the imagination'. ${ }^{73}$ Despite holding the same opinion just a few short years before, Ross was now so sure of Laveran's parasite that he compared Lawrie's disbelief in it to a disbelief in the existence of the moon. Lawrie challenged supporters to prove that what

\footnotetext{
${ }^{68}$ Mary Kingsley, Travels in West Africa: Congo Francais, Corisco and Cameroons (London: Macmillan, 1897) p. 681.

${ }^{69}$ Ronald Ross, 'Malaria and the Mosquito' The Pioneer, Saturday 3 August 1895, p. 3.

${ }^{70}$ Ronald Ross, Memoirs, p. 126.

${ }^{71}$ As I have written about elsewhere: Emilie Taylor-Brown, "Petty Larceny" and "Manufactured Science": Nineteenth-Century Parasitology and the Politics of Replication' in Replication in the Long Nineteenth Century: Re-makings and Reproductions ed. by Julie Codell and Linda K. Hughes (Edinburgh: Edinburgh University Press, 2018) pp. 67-83 (p. 73).

${ }^{72}$ Martin Willis, Vision, Science, and Literature 1870-1920: Ocular Horizons (Pittsburgh: University of Pittsburgh Press, 2016) pp. 1-2.

73 'The Cause of Malaria. Extract from an Address Delivered at the Grant Medical College, Bombay, April 4th 1896 by Surgeon-Lieutenant-Colonel E. Lawrie, M.B., Residency Surgeon, Hyderabad', British Medical Journal 1.1845 (1896) 1135-38 (p. 1135).
} 
Laveran had seen beneath the microscope was not simply a degenerated red blood cell or immature white blood cell, and, as the debate raged on, Ross responded that Lawrie's position was akin to suggesting that the moon was made of 'green cheese':

Any attempt to prove that the malaria parasite is not a degenerate red corpuscle is like an attempt to prove that the moon is not made of green cheese; most of us, I believe, are pretty confident that our satellite is not composed of that substance, but I fancy it would be somewhat difficult to prove the point, especially in the limits of a letter to the Daily Press, against a person obstinately possessed of the green cheese theory. ${ }^{74}$

We now know that Laveran's parasite is indeed the parasite responsible for malaria. However, the point here is not that Ross was correct the second time around, but that the scientific method-with its imagined objectivity and impartiality - is an idealisation that rarely maps onto science as a material practice.

As Willis argues, 'microscopic vision' became one of the most influential modalities of seeing across the nineteenth century. Whilst the microscope roundly failed to deliver the objectivity it promised, it nevertheless shaped a new kind of visual experience that emerged at the intersections of experimental practice, public understandings of science, and imaginative responses to scientific knowledge. This new kind of visual experience and the tensions it embodied were encoded in the many contradictions at work in the Holmes canon, which Jonathan Smith argues 'were absorbed from and participated in the cultural debate about the scientific method' ${ }^{75}$ Smith ultimately conceptualises Holmes's engagement with the cultural imaginary of science in terms of 'complementarity between the attic [...] and the magnifying glass'. These metaphors, which he borrows from Gian Paolo Caprettini, correspond to Holmes's collection and storage of facts on the one hand and to his deductive powers on the other.

This complementarity is embodied by the kind of diagnostic parlour trick for which Holmes is most famous. Upon first meeting a stranger, Holmes uses his expert knowledge and specialist gaze to glean revealing biographical information. The practice was famously modelled on

${ }^{74}$ London, LSHTM. RC. GB 0809 Ross/39/03. Clipping: 'Existence of the Malaria Parasite' The Pioneer, 28 September 1897, n.p.

${ }^{75}$ Jonathan Smith, Fact and Feeling: Baconian Science and the Nineteenth Century Literary Imagination, p. 215. 
Edinburgh physician Joseph Bell. Bell illustrated his fabled diagnostic method for the Pall Mall Gazette with an anecdote in 1893:

A man walked into the room where I was instructing the students and his case seemed to be a very simple one [...] "Of course, gentlemen", I happened to say, "he has been a soldier in a Highland regiment, and probably a bandsman". I pointed out the swagger in his walk, suggestive of the piper; while his shortness told me that if he had been a soldier it was probably as a bandsman. In set, he had the whole appearance of one of the highland regiments. ${ }^{76}$

As Bell notes, he was subsequently proven incorrect: 'the man turned out to be nothing but a shoemaker and said he had never been in the army in his life'. 'This', he admitted, 'was rather a floorer'. However, being 'absolutely certain' that he was right, he had the man detained by his strongest clerks and forcibly stripped him. He found a small blue ' $D$ ' branded on his skin, indicating that the man was a deserter from the army, and thus vindicating his deductions.

Aside from the reprehensible biopolitics of forcibly stripping a man to prove a point (the outcome of which does not appear to contribute to a diagnosis), the encounter is not a good demonstration of the scientific method that Bell advocates. Bell bases his hypothesis on the characteristic 'swagger' of the Highland piper, his shortness and build giving away role and regiment. However, this seems like thin evidence. And although the man did in the end have an association with the army, his regiment and role were never explicitly established. It was also not clear how long he was associated with the army or when he deserted. Moreover, Bell was not able to deduce anything else about the man like his current practising profession as a shoemaker. Nevertheless, the anecdote was reprinted in several later articles on Bell as a triumph of his powers of deduction because it played into a popular fantasy about the superior interpretive skills of medical experts.

Similar anecdotes circulated. In an article in The Bookman in 1892, Conan Doyle recounted Bell's treatment of another highland soldier:

"Ah!" he would say to another man, "you are a soldier, a non-commissioned officer, and you have served in Bermuda. Now, how did I know that,

76 'The Original of "Sherlock Holmes". An Interview with Dr Joseph Bell' Pall Mall Gazette (Thursday 28 December 1893) 1-2. 
gentlemen? He came into the room without taking his hat off, as he would go into an orderly's room. He was a soldier. A slight, authoritative air, combined with his age, shows he was a non-commissioned officer. A slight rash on the forehead tells me he was in Bermuda, and subject to a certain rash known only there". ${ }^{77}$

The story was repeated in Conan Doyle's Memories and Adventures but with some of the details altered. This time it is Barbados, not Bermuda, and the rash is now elephantiasis - a condition characterised by extreme swelling of limbs (most often the legs) and thickening of the skin and subcutaneous tissue.

In one of his best cases he said to a civilian patient: "Well, my man, you've served in the army." "Aye, sir." "Not long discharged?" "No, sir." "A Highland regiment?" "Aye, sir." "A non-com. officer?" "Aye, sir." "Stationed at Barbados?" "Aye, sir." "You see, gentlemen," he would explain, "the man was a respectful man but did not remove his hat. They do not in the army, but he would have learned civilian ways had he been long discharged. He has an air of authority and he is obviously Scottish. As to Barbados, his complaint is elephantiasis, which is West Indian and not British". To his audience of Watsons it all seemed very miraculous until it was explained, and then it became simple enough. ${ }^{78}$

Bell-or perhaps Conan Doyle in embellishing the memory-utilises the geographical specificity of tropical illness to discern this unnamed patient's travel history. The characterisation of his fellow students as 'an audience of Watsons' suggests that this particular memory is thoroughly entangled with his creation of Holmes, who, of course, makes a similar diagnosis of Watson when they first meet. However, in this case, Bell's strategy would not have been a particularly effective one for deducing where the soldier was stationed because elephantiasis was not confined to Barbados. Rather it was prevalent in many parts of the empire, including India and Africa. Patrick Manson's elucidation of the mosquito vector for this condition in 1877 famously took place in Amoy, China.

${ }^{77}$ Raymond Blathwayt, 'A Talk with Dr Conan Doyle' The Bookman 2.8 (May 1892) 50-51 (p. 50).

${ }^{78}$ Arthur Conan Doyle, Memories and Adventures (Boston: Little, Brown, and Company, $1923)$ pp. 20-21. 
Nonetheless, this kind of encounter became a central fiction of the scientific detective. In making Holmes the 'literary embodiment' of his memory of Bell, Conan Doyle adopts a mode of diagnostic reasoning that is more about logic, story-telling, and showmanship than it is about science. As Holmes himself remarks in A Study in Scarlet: 'You know a conjurer gets no credit once he has explained his trick; and if I show you too much of my method of working, you will come to the conclusion that I am a very ordinary individual after all' (34). Other fictional detectives also play on the showmanship of detection by emphasising the superior gaze of the detective over the ordinary medical man. Fictional detective, Dr Thorndyke, acerbically invites his Watson-counterpart, Dr Jervis, to solve the mystery in $D r$ Thorndyke Intervenes: 'You know what the known facts are, Jervis, and you will see for yourself, if you consider them critically, which are the significant ones' (168). 'Go carefully over all the facts in [your] possession', he urges, 'and I think [you] will find that some extremely interesting conclusions will emerge' (165).

Holmes often baits Watson to do the same in an attempt to demonstrate the teachability of the science of detection. However, both Holmes and Thorndyke repeatedly outshine their companions by making those dazzling inductions, deductions, and abductions of which the general reader and poor Drs Watson and Jervis are not capable. This, of course, is the long-standing joke of the genre: the detectives' companions and wethe readers-are often denied access to critical information: we are given the magnifying glass but not the attic. Thus, we are unknowingly tricked into making that 'capital mistake' of theorising with incomplete data.

\section{(Re)diagnosing the Colonial Encounter}

In 'The Adventure of the Dying Detective' (1913), English planter and antagonist Culverton Smith, who has made a study of the mysterious Sumatran disease that forms the basis of the plot, compares his skills with Holmes:

"He is an amateur of crime, as I am of disease. For him the villain, for me the microbe. There are my prisons," [...] pointing to a row of bottles and jars which stood upon the side table. "Among these gelatine cultivations some of the very worst offenders in the world are now doing time". (1176) 
Here we are invited to consider how knowledge about microbes and about criminals intersect. Thirteen years earlier, in a remarkably similar scene, Ross had held up a glass phial during a lecture given at the Royal Society of Arts and exclaimed:

We now keep diseases labelled in our laboratories; we measure them; we examine them under the microscope $[\ldots]$ we prevent great outbreaks and save the lives of thousands [...] we put plague, cholera, typhoid, diphtheria in bottles so that we can hold them in our hands and look at them. It is my privilege to describe to you tonight one of the most remarkable of these revelations. In this small glass phial I have some of the deadly fevers of the west African marshes. ${ }^{79}$

Both scenes invoke the materiality and confinement of pathogens in celebration of the power of the diagnostic or investigative gaze. Ross forges an association between 'examining [microbes] under the microscope' and preventing outbreaks - an elision of 'seeing' and 'doing' that linguistically characterised popular accounts of microbiology. Conan Doyle indulges in a kindred fantasy in A Study in Scarlet. In the first few pages, Holmes develops the 'Sherlock Holmes test' for detecting blood, which promises to make 'hundreds of men now walking the earth $[\ldots] \mathrm{pa}[\mathrm{y}]$ the penalty of their crimes' (14). Here the complications of the legal system are sidelined in favour of a reductive model of identification-as-power.

Whilst the test is ostensibly for detecting invisible traces of blood at crime scenes, it discursively intersects with a broader association between the examination of the blood and biopolitical control. In 1898, for example, the Indian Medical Gazette had recommended that returning soldiers should be confined to hospitals and kept there 'as long as the microscope shows them capable of being a source of infection to others' ${ }^{80}$ In this way, the microscope was able - through the act of visualisation-to neutralise the threat posed by soldiers as conduits of tropical dysentery. As an advertisement for Bausch and Lomb Optical Company demonstrates in 1920, the microscope was increasingly conceived as a weapon in the 'crusade against disease'. 'Invisible, they were also invincible', it argued (in reference to microorganisms), 'but once discovered and identified, science

79 'Malaria and Mosquitoes' Journal of Society of Arts (30 November 1900) 18-26 (p. 18).

80 'Infection of Healthy Areas by Diseased Troops' Indian Medical Gazette 33.12 (1898) p. 463. 
devised safeguards against infection, and commenced its patient cataloguing of these, man's ancient enemies'.

Such language supports a slippage between microbe and criminal that furnishes Holmes's bloodhound-like pursuit of the 'scarlet thread of murder' with new currency. Like a literary embodiment of the haemoglobin reagent he invents in a Study in Scarlet, Sherlock Holmes is able to detect and make visible what others cannot. As Otis argues, he acts as an 'imperial leukocyte or antibody', sticking close to his suspects until he identifies them-his adventures a dramatisation of an imperial immune response. ${ }^{81}$ Ross drew on a similar parallel in his Memoirs, insisting that 'phagocytes have often been considered to be the policemen of the blood'. Antibodies are like detectives, he explains; they identify the pathogen in preparation for phagocytes, who, 'instead of arresting the culprit, swallow him on the spot' ${ }^{82}$ As Servitje points out, however, much more is needed for the successful defence of the body or the nation. Holmes and Watson 'find the discrete pathogens and "isolate them", but they ignore the cultural medium that allows them to thrive $[\ldots]$ they allay the symptoms rather than curing the social disease'. ${ }^{83}$ This is perhaps a consequence of Conan Doyle's engagement with discourses of microbiology, which privileged identification of pathogens over the more long-term work of public health and sanitation.

Robert Peckham and others have explored the rise of a 'politicalbacteriological imaginary' from the mid-nineteenth century, which contributed to the discursive formation of the 'diseased criminal' and, as I explore here, its counterpart: the 'criminal disease'. ${ }^{84}$ In 1922, The Daily News reported on 'an assassin whose criminal record is more formidable than that of all Scotland Yard's enemies put together' and a murderer who had 'killed thousands of persons in Great Britain last year'. ${ }^{85}$ The culprits were called influenza and tuberculosis. Other reporters employed similar rhetorical strategies insisting that 'disease is the most elusive criminal in the world', and dubbing the Report of the Medical Research Council

${ }^{81}$ Laura Otis, 'The Empire Bites Back: Sherlock Holmes as an Imperial Immune System' Studies in 20th Century Literature 22.1 (1998) 31-60 (p. 33).

${ }^{82}$ Ross, Memoirs p. 138.

${ }^{83}$ Servitje, p. 164.

${ }^{84}$ See, for example, Robert Peckham (ed) Disease and Crime: A History of Social Pathologies and the New Politics of Health (London: Routledge, 2014).

85 'Doctors as Detectives. On the Track of Mankind's Greatest Enemies' The Daily News, Thursday 20 April 1922, p. 5. 
1920-21 a 'new book of murderers', which reconstructs the 'thrill and romance of medical research' and was 'more subtle, more daring, and more courageous' than the 'adventures of Sherlock Holmes' ${ }^{86}$

In popular medical texts microbes and their vectors were also criminalised. Scottish doctor Ronald Campbell Macfie wrote a popular history of medicine in 1907-which he hoped would be 'of interest to the Profession as well as the general public' - wherein he conceptualised disease as 'homicide' carried out by murderous blood-dwelling assassins. ${ }^{87}$ 'This microbe makes murder a fine art', he wrote of the malaria parasite (145); meanwhile he characterised the parasite of sleeping sickness as 'a noted criminal' (144). In Paul de Kruif's Microbe Hunters (1926), he invoked a similar framework, identifying the mosquito as 'the criminal in the malaria mystery'. ${ }^{8}$ $\mathrm{He}$ insisted that Italian parasitologist, Giovanni Battista Grassi, who was working on the malaria problem at the same time as Ross, 'compared himself to a village policeman trying to discover the criminal in a village murder' (300). De Kruif was likely referring to an article published by Grassi in Nature in response to the publication of Ross's Memoirs (1923). In defence of his claims for priority in the mosquito-malaria discovery, Grassi explained how his methodology differed from Ross's method of trial and error:

I conceived, therefore, and recommended in my paper (1889) the method of limiting the search for intermediate hosts by a preliminary detection of suspected forms. To explain my meaning by a similitude, if in a village of a thousand inhabitants a theft has been committed, it will be very difficult to discover the thief, unless it is first established, by appropriate investigations, which persons fall under suspicion. Once in possession of the list of suspects, it is much easier to find the culprit, as every detective knows full well. ${ }^{89}$

${ }^{86}$ 'Tracking the Assassins of Everyday Life. Romance of the Medical Sherlock Holmes' Yorkshire Evening Post, Friday 13 January 1922, p. 6; 'Doctor Detectives. Tracking Disease Criminals. Research Work Romance' Cairns Post, Monday 10 April 1922, p. 7.

${ }^{87}$ Ronald Campbell Macfie, The Romance of Medicine (London: Cassell and Company, 1907) p. v.

${ }^{88}$ Paul de Kruif, Microbe Hunters (New York: Harcourt, Brace and Company, 1926) p. 278. Ross threatened to sue the publishers of the British edition of Microbe Hunters for libel and they subsequently omitted the chapters on Ross and David Bruce from the book. Ross, Aldo Castellani, George Low, and David Nabarro published their objections in a letter to the British Medical Journal, see: Aldo Castellani, George C. Low, David Nabarro and Ronald Ross, 'A Disclaimer' British Medical Journal, 2.3430 (2 October 1926) p. 617.

${ }^{89}$ Giovanni Battista Grassi, 'The Transmission of Human Malaria' Nature 113.2835 (1 March 1924) 304-07 (p. 304). 
Grassi's choice of words might well have in turn been informed by Lt. Col. Walter Gaven King's review of Ross's Memoirs published in Nature the preceding year. King, then sanitary officer in Madras, insisted that the book would be interesting to a 'wide circle of readers, in that the subjects treated must appeal to the Imperialist, the political economist, the sanitarian of the tropics, and the cosmopolitan science research worker'. In 'the laborious experimental efforts of the author' will be found, he argued, 'a tale $[\ldots]$ of relentless search for a scientific truth, with its recurring disappointments, baffled schemes, renewed hopes, and ultimate victory, which, in entrancing interest, may compete with Sherlock Holmes's efforts at his best'. ${ }^{90}$ King's comments and Grassi's 'similitude' demonstrate the widespread currency of the tropes of crime fiction to characterise the relationship between tropical pathologists and tropical disease. In one of his medical notebooks, Ross scribbled 'villain classification' above a list of causative agents of skin disease, invoking a similar juxtaposition between criminals and pathogens, and suggesting that the framework was not only communicative but also hermeneutic. ${ }^{91}$

For a popular audience, the discursive relationships between crime and pathology were dramatically expressed in stories like 'The Adventure of the Blanched Soldier' (1926) where tropical illness narratively replaces crime altogether and Holmes is called upon not to detect so much as to diagnose. The story is set in 1903 just after the conclusion of the AngloBoer war and is one of the few narrated by Holmes. One morning he receives a visit from $\mathrm{Mr}$ James $\mathrm{M}$. Dodd who entreats him to investigate the strange behaviour of his comrade-in-arms Godfrey Emsworth. He has not heard from Godfrey, his closest pal, for six months and is certain Godfrey's father, Colonel Emsworth, is keeping him in an outbuilding against his will. When Dodd briefly glimpses Godfrey peering through his window, he is no longer the 'manly lad' he once knew. With a 'deadly pale' face and a 'slinking', 'furtive', 'guilty' demeanour, he is a complete contrast to Dodd__ 'a big, fresh, sunburned, upstanding Briton'. ${ }^{92}$ After a few questions, Holmes concludes that Godfrey has contracted leprosy,

${ }^{90}$ W. G. King, 'Memoirs: With a Full Account of the Great Malaria Problem and its Solution' Nature 112.2801 (7 July 1923) 3-5 (p. 3).

${ }^{91}$ London, LSHTM. RC. GB 0809 Ross/157. Undated Notebook.

${ }^{92}$ Arthur Conan Doyle, 'The Blanched Soldier' The Complete Stories of Sherlock Holmes (1926; Ware: Wordsworth Editions, 2008) pp. 1254-69 (p. 1256). 
which he notes 'is not uncommon in South Africa'. ${ }^{93}$ Holmes and Dodd travel to Colonel Emsworth's house where Godfrey relays his story.

In a wounded state, having been shot in the shoulder and suffering from severe exhaustion, Godfrey had stumbled upon an apparently empty building near Pretoria and collapsed into one of the many unmade beds. His tale is framed by a climatological discourse that associates danger and pathology with the tropical environment. He was ushered into the building by 'a deadly, sickening sort of cold, very different from a crisp, healthy frost', and awakens to the 'African sun' flooding through the windows. What that sun illuminates is an 'extraordinary nightmare' of 'strange monstrosities'. He had stumbled across a leper hospital and slept in a leper's bed. The hospital's medical superintendent remarks: 'you are in far greater danger here than ever you were on the battlefield' setting up a medico-military parallel that provides a lexis for conceptualising the dynamic of medical specialism during the story's dénouement. Godfrey subsequently made his way back to England where he began to develop the symptoms of leprosy. His parents confined him to the outbuilding to prevent him from being removed to a leper hospital and segregated for the rest of his life.

Holmes asks Emsworth's attendant surgeon, Mr Kent, if he is an authority on such diseases, 'which are [...] tropical, or semi-tropical in their nature'. The surgeon admits that he is not a specialist, somewhat defensively explaining that he has the 'ordinary knowledge of the educated medical man'. Holmes's framing of leprosy as a tropical disease follows Patrick Manson's inclusion of the complaint in his seminal textbook Tropical Diseases published in 1898, in which he described it as 'an important element in the pathology of nearly all warm countries'.${ }^{94}$ Rod Edmond argues that Manson's decision to include leprosy, despite it having no specific geographical or climatic associations with the tropics, represents 'an attempt to put a fence around Europe' and protect it from the tropical world. ${ }^{95}$ Manson admits that lepers exist in Australia, the United States, Canada, and Iceland but insists that his designation is justified-that although not caused by them, leprosy is associated with 'social conditions' like 'uncleanly habits, squalor, dirt, and poverty', which he locates in the

${ }^{93}$ Arthur Conan Doyle, 'The Blanched Soldier', p. 1268.

${ }^{94}$ Patrick Manson, Tropical Diseases: A Manual of the Diseases of Warm Climates, p. 417; Cutaneous leishmaniasis or Oriental Sore, a tropical disease caused by a protozoan parasite, was often called 'white leprosy' owing to its characteristic lesions.

${ }^{95}$ Rod Edmond, 'Returning Fears: Tropical Disease and the Metropolis', p. 184. 
colonial environment (418). Conan Doyle thus plays into a common anxiety about the colonial encounter as morally and physically pathogenic. Godfrey's 'slinking' guilt and the undertones of sexual transmission implicit in sharing a bed and in Dodd's 'real love' for his comrade- 'the sort of friendship which can only be made when one lives the same life and shares the same joys and sorrows'-further compounds this anxiety.

Holmes, however, does not give up hope so easily. He brings with him a specialist: renowned dermatologist Sir James Saunders, who is able to absolve Godfrey of his fate by re-diagnosing his complaint as 'pseudoleprosy' or 'itchthyosis' - a curable skin disease that merely resembles the symptoms of leprosy. He speculates that Godfrey's complaint is psychosomatic, owing to the mental trauma that he had been through, illustrating the devastating impact of colonial conflict on the returning British body, but also suggesting that this impact might be neutralised by British medical expertise. Holmes observes that general practitioner, Mr Kent, is in awe of the medical specialist: 'The prospect of an interview with Lord Roberts would not have excited greater wonder and pleasure in a raw subaltern than was now reflected upon the face of Mr. Kent'. His military simile (Lord Roberts was Commander-in-Chief of the Forces and involved in the Indian Rebellion, the Second Anglo-Afghan War, and the AngloBoer War) recalls Conan Doyle's martial understanding of white blood cells and creates a hierarchy between the medical specialist and the general practitioner that relies on a collapsing of medical and imperial authority. ${ }^{96}$

Conan Doyle also strategically deploys the hierarchy of medical specialism in 'The Adventure of the Dying Detective' (1913). In this tale, Watson finds Holmes suffering from a tropical illness but is hurt when he is denied the opportunity to examine him:

'You have [no confidence] in me?'

'In your friendship certainly. But facts are facts, Watson, and after all you are only a general practitioner with very limited experience and mediocre qualifications [...] Shall I demonstrate your own ignorance? What do you know pray of Tapanuli fever? What do you know of the black Formosa corruption?’

'I have never heard of either.'

${ }^{96}$ Holmes's 'renowned dermatologist' might have been inspired by Malcolm Morris, who Conan Doyle met on his Berlin trip and recalls fondly in his autobiography Memories and Adventures, serialised in The Strand two years earlier (October 1923 to July 1924). 
'There are many problems of disease, many strange pathological possibilities, in the East, Watson.'

As Susan Cannon Harris has observed, here is the 'voice of the specialist declaring that the "general practitioner" is not competent to treat this kind of complaint. The "pathological possibilities" of "the East" require a new kind of medico-criminal knowledge'. ${ }^{97}$ Such an opinion is what led to the establishment of the London and Liverpool Schools of Tropical Medicine at the turn of the century. In 1894, an article in the British Medical Journal had criticised the 'general absence in the English medical schools of any provision for teaching or acquiring even a rudimentary knowledge of the important subject of tropical disease'. The article referred to a recent address given at the Indian Medical Congress by Ernest Hart, medical writer and editor of the journal. 'Considering England's position as incomparably the greatest tropical as well as colonial power', it is unacceptable, Hart asserted, that the 'hundreds of young medical men [sent] to combat disease in tropical countries' should meet dangerous diseases that they have never heard of and learn by 'dearly bought experience' what they ought to have learnt in medical school. ${ }^{98}$

In 1897, Patrick Manson wrote to the British Medical Journal arguing similarly that a specialised form of training was needed for colonial doctors owing to the unique knowledge and diagnostic methodologies required when dealing with tropical diseases: 'a physician may be competent to deal with diseases in England but sadly incompetent to deal with disease in Africa'. In making this argument, he characterised tropical diseases as predominantly caused by parasites and highlighted a need for specific training on how to identify them correctly beneath the microscope. In illustration of his point, he insisted:

Ten chances to one if one asks a student or even a medical practitioner to set about examining a patient for filariae, he will prepare a very fine film of blood, just as would be suitable for the demonstration of bacteria $[\ldots]$ with

\footnotetext{
${ }^{97}$ Susan Cannon Harris, 'Pathological Possibilities: Contagion and Empire in Doyle's Sherlock Holmes Stories' Victorian Literature and Culture 31.2 (2003) 447-66 (p. 447).

98 'Ignorance of Tropical Diseases' British Medical Journal 2.1774 (29 December 1894) 1491-92.
} 
a twelfth of an inch immersion lens and an Abbe condenser [however] filariae should be sought with an inch objective, otherwise they will be missed. ${ }^{99}$

The unique diagnostic methodologies of the specialist are unsubtly paralleled by Holmes who is to the ordinary policeman what Watson is to the tropical specialist.

The real reason Holmes doesn't want Watson to examine him, however, is because he is only pretending to suffer from a tropical illness in order to entrap antagonist Culverton Smith, an English plantation owner who murdered his nephew with a tropical pathogen. By having Holmes feign illness, Conan Doyle places his tale in the context of debates about tropical invalidism, which Upamanyu Pablo Mukherjee characterises as part of a pathology of 'imperial intimacy'. ${ }^{100}$ Identifying a tension between Holmes as a 'defender of the British world order' and Holmes as a 'drugriddled, neurotic' malingerer, Mukherjee argues that stories like 'Dying Detective'

dramatise a particular set of anxieties about the decay, contamination, or dilution of 'Englishness' in the era of the British world empire, and that these anxieties are often staged through the language of tropical infection, disease, and detection. (80)

In Conan Doyle's description of Smith, Mukherjee reads the 'vivid signs of tropical toxicity' that were often interpreted in the bodies of English returnees (84). Smith is 'small and frail, twisted in the shoulders and back' with 'a great yellow face' that suggests both the jaundice of chronic ill health and a racialised cultural contamination, emphasised by the Orientalist overtones of the 'small velvet smoking cap perched coquettishly' on his 'high bald head'. Smith is also connected to tropical toxicity through his choice of murder weapon. As Cannon Harris argues, criminal poisoning was popularly perceived to be 'a crime peculiar to the tropics' and thus cases of homicidal poisoning in London suggested to many

\footnotetext{
${ }^{99}$ Patrick Manson, 'The Need for Special Training in Tropical Disease' British Medical Journal 2.2023 (7 October 1899) 922-26.

${ }^{100}$ Upamanyu Pablo Mukherjee, " "Out-of-the-Way Asiatic Disease”: Contagion, Malingering and Sherlock's England' in Literature of an Independent England: Revisions of England, Englishness, and English Literature ed. by Michael Gardiner and Claire Westall (Basingstoke: Palgrave Macmillan, 2013) pp. 77-104 (p. 79).
} 
readers that 'Britain's imperial expansion had allowed this vice to spread from the colonial dominions to the heart of the metropolis' ${ }^{101}$

As she observes, Conan Doyle frequently deploys the metaphor of colonial contagion in ways that reflect 'a contemporary rhetorical trend that lumped drugs, organic toxins, and infectious agents together as foreign-born biocontaminants returning from the colonies to afflict the English' (449). The poisoned dart in The Sign of Four (1890), the Indian snake in 'The Adventure of the Speckled Band' (1894), the South American poisoned arrows in A Study in Scarlet (1887) and 'The Adventure of the Sussex Vampire' (1924), and the pathogen-loaded spring box in 'The Adventure of the Dying Detective' (1913) represent undifferentiated anxieties about the relationship between foreign pathogens, tropical nature, and criminality. These stories play into a recurring plot in which 'exotic toxins' reveal the pathological possibilities of Britain's imperial project; as Holmes tells us in 'The Speckled Band':

The idea of a snake instantly occurred to me, and when I coupled it with my knowledge that the doctor was furnished with a supply of creatures from India, I felt that I was probably on the right track. The idea of using a form of poison which could not possibly be discovered by any chemical test was just such a one as would occur to a clever and ruthless man who had had an Eastern training. ${ }^{102}$

Here the flora and fauna of empire provide natural resources for the criminal to exploit. Through narrative manoeuvres like these, readers are reminded that 'like the Indian snake that sinks its fangs into Dr Roylott, the Empire sometimes bites back' (452).

A ruthless man with an 'Eastern training' also describes the antagonist of 'Dying Detective' who murders his nephew and attempts the same with Holmes by loading a spring with a tropical pathogen concealed within a box. The spring is 'like a viper's tooth', recalling both the swamp adder of 'The Speckled Band' and the microbial cobras of Conan Doyle's popular medical writing. The puncture of the body and subsequent injection with poison enacted by the coiled spring, swamp adder's fangs, and the poisoned arrows and darts, all bring to mind another archetypal puncturing in tropical space: the bite of the mosquito-omnipresent in tropical travel

${ }^{101}$ Susan Cannon Harris, p. 449.

${ }^{102}$ Arthur Conan Doyle, 'The Adventure of the Speckled Band' Strand Magazine (February 1892) 142-57 (p. 157). 
and, by 1898, decisively associated with tropical illness. The doubleness of these leitmotifs - of criminality and disease - encodes a latent pathogenicity into the tropical encounter that is also reflected in Conan Doyle's other fictional characterisations of empire.

In 'The Story of the Brown Hand' published in the Strand Magazine in 1899, the narrator, English neurologist Dr Hardacre, remarks that 'bloated organs, gaping cysts, distorted bones, [and] odious parasites' are 'a singular exhibition of the products of India'. ${ }^{103} \mathrm{He}$ has come to help his uncle, latterly a famous surgeon in charge of an 'Oriental Hospital', but now a 'broken man' with 'very pronounced nervous symptoms' from forty years residence in India. His uncle, we discover, is being haunted by the ghost of a one-handed Indian patient who nightly appears to search among the 'odious line of glass jars with their relics of disease and suffering' for his severed limb. Conan Doyle conforms to the hunting aesthetic that I examined in the previous chapter when he describes Hardacre closing the door of the laboratory with 'the pleasurable thrill of anticipation with which the sportsman takes his position beside the haunt of his game' (503).

A similar equivalence between sportsmanship and science is made in Conan Doyle's The Voice of Science, published in the Strand in 1891. In this short tale, we learn of Mrs Esdaile, the honorary secretary of the ladies' branch of the local Eclectic Society, who holds regular scientific conversaziones in her home: 'On her pleasant lawns in the summer, and round her drawing-room fire in the winter, there was much high talk of microbes and leucocytes and sterilised bacteria'. Her house is filled with exotic specimens and trophies, from Galapagos turtles to bits of Triassic rock, to a stuffed ornithorhynchus, and-notably - 'the bacillus of Koch cultivated on gelatine'. ${ }^{104}$ The collector's gaze emphasises the materiality of these 'exotic' artefacts, recalling Smith's 'rows of bottles and jars' and implying that the threat posed by the colonies might be mastered by the practices of taxonomy. Nevertheless, stories like 'Dying Detective' dramatically express the permeable boundaries of classification by relying on the collision of tropical mystery and medical authority embodied in the

${ }^{103}$ Arthur Conan Doyle, 'The Story of the Brown Hand' Strand Magazine (May 1899) 499-508 (p. 502).

${ }^{104}$ Arthur Conan Doyle, 'The Voice of Science' Strand Magazine (March 1891) 312-17 (p. 313). 
narrative possibilities of tropical medicine, in the 'strange pathological possibilities of the East'.

In 'Dying Detective', the plot hinges on the obscurity of Holmes's unnamed tropical illness, described as 'an out-of-the-way Asiatic disease' and 'a coolie disease from Sumatra'. The fictional 'Tapanuli fever' and 'black Formosa corruption' serve as foils that expose the lacunae in Watson's medical knowledge and keep him and the reader in suspense. However, this same ambiguity also suggests-after the tale's dénouement - that the mystery of 'the East' provides opportunities for deceit which place Holmes in uncomfortable proximity to the criminals he is charged to apprehend. Holmes's malingering aligns him not only with tropical invalids but also with those who pretended to suffer from ill health for insurance purposes. As Mukherjee observes, the year that 'Dying Detective' was published also saw the publication of John Collie's Malingering and Feigned Sickness, a book that sought to expose a perceived rise in fraudulent compensation claims, especially among the English working classes. It tapped into a 'national panic about the decay of the moral and physical abilities of English working-class men that went at least as far back as the Boer War' (86). Malingering was also, Mukherjee argues, a common accusation levelled against 'indigenous labourers everywhere in empire', thus Holmes's behaviour invokes triply the faking of illness by some English workers, the genuine tropical invalidism of some returnees, and the racialised 'laziness' attributed to colonial labourers. For Mukherjee, 'Dying Detective'

confirms a pathological proximity between the coolies whose ghosts flit at the margins of repressed imperial consciousness, the detective who is responsible for the defence of the imperial status quo, and the workers whose alleged shirking was seen as a symptom of an Englishness infected with the consequences of global overreach. (87-88)

Notwithstanding Mukherjee's persuasive analysis, Collie's advice that doctors should develop a familiarity with the methods of the malingerer opens up yet another interpretive avenue. By carrying out his act with 'the thoroughness of a true artist', including starving himself and applying extensive makeup, Holmes is able to entrap Smith and remove him from his affluent position (embodied by his property with its 'smug respectability' and Kensington address). Therefore, his malingering is also a productive 
form of 'work' that protects the English middle classes, bolstering the political authority of practitioners of tropical medicine.

\section{Criminal Natures}

Upon examining some blood at the scene of a murder, fictional scientist Paul Gilchrist utters the following words:

I had studied Eastern diseases with care and was well acquainted with the peculiar nature of this strange parasite. Was it possible that I held in my hand the means of clearing my friend? ${ }^{105}$

His friend Harry Lidderdale has been framed for the murder of his old flame, Alma Colthurst, whose death had been prophesised the night before by a Brahmin chiromancer. Being the kind of man of science who carries his laboratory with him wherever he goes-'I suddenly remembered that I had some microscopical slides and a cover glass in my pocket'-Gilchrist is able to investigate on behalf of his friend and obtains a sample of the killer's blood left on a broken wine glass. What he sees in the sample of blood (the nematode parasite Filaria perstans) leads to the absolution of his friend by the diagnostic incrimination of another. Gilchrist's training in 'Eastern diseases' is crucial in helping him solve the crime in a story that seems almost satirical in its investment in both sensationalism and science.

In just 13 pages, this story gives us a spurned lover, a doomed romance, a Brahmin prophesy, a doppelgänger, a murder investigation, diamonds in South Africa, and a rare and deadly tropical disease. The story, written by children's writer Elizabeth Thomasina Meade Smith and Crystal Palace GP Dr Edgar Beaumont under the pseudonyms L. T. Meade and Clifford Halifax M.D., was published in the Strand Magazine in 1896-three years after Holmes had gone over the edge of the Reichenbach falls in 'The Final Problem'. The tale was part of a series called 'The Adventures of a Man of Science' and, like 'Dying Detective', the plot is built around the obscurity and specificity of a tropical pathogen. Just as Victor Savage's 'surprising' contraction of 'an out-of-the-way Asiatic disease in the heart of London' arouses Holmes's suspicions, the presence in a blood sample

${ }^{105}$ L. T. Meade and Clifford Halifax, 'The Adventures of a Man of Science, IV - The Sleeping Sickness' Strand Magazine 12 (1896) 401-14 (p. 411). 
of nematode worms specific to the west coast of Africa alerts Gilchrist to the killer's identity. In the scene with which I opened, Gilchrist discovers that the killer's blood is tainted with filaria parasites - a fact which exposes his travel history in a literalisation of the aphorism: you can take the man out of [the Tropics], but not [the Tropics] out of the man:

The blood $[\ldots]$ contained a large quantity of the remarkable parasite filaria perstans. As this parasite has never been contracted anywhere except on the West Coast of Africa, this fact proved at a glance that it was not the blood of Mrs. Colhurst. It must therefore follow, as a natural consequence, that it could only come from a person who had been in West Africa. (411)

Gilchrist subsequently, and fortuitously, hears of a patient with sleeping sickness in London (who turns out to be the killer) when visiting a 'Harley Street doctor who was celebrated for his treatment of Eastern disease' (411). The specialist, a 'Dr. Materick', is perhaps a loosely veiled reference to Dr Patrick Manson, who championed a connection between filaria perstans and sleeping sickness in the 1890s. ${ }^{106}$

Manson, now widely considered to be a founder of modern tropical medicine, had famously uncovered the mosquito as a vector for filarial parasites in 1877. In 1889, after spending several years in medical practice in Hong Kong, he returned to London and became a lecturer in tropical diseases at St George's Hospital. Conan Doyle also likely meant to reference Manson when he had Watson remark in 'Dying Detective' that 'Dr Ainstree, the greatest living authority upon tropical disease is now in London'. Manson championed an environmentalist view of tropical diseases, which he believed were mostly caused by animal parasites that relied on the specific flora and fauna of warm climates. In his seminal textbook Tropical Diseases, he argued that tropical illness was geographically restricted because, unlike bacterial infections, for a tropical disease to become endemic it required 'the double condition of the introduction of not only the germ itself but also of the intermediary'. ${ }^{107}$ Thus, in 'Dying Detective', Culverton Smith must contrive a novel transmission medium (the spring box) in order to affect his plan, whilst in Meade and Halifax's

${ }^{106}$ Manson discovered F. perstans in the blood of a West African patient suffering from sleeping sickness in 1890 and proposed a connection, which was later disproven by the Royal Society Sleeping Sickness Commission of 1902.

${ }^{107}$ Patrick Manson, Tropical Diseases. A Manual of the Diseases of Warm Climates 4 th edn (London: Cassell and Company, 1912) p. xiii. 
story, the very specific geographical distribution of sleeping sickness is mobilised to prove the killer's recent travel history.

Although the British killer's motive for murder is garden-variety jealousy, he admits that immediately after killing Alma - 'in a fit of fury'-he ran to fortify himself from the decanter, as he had 'been queer for days and weeks', and was subsequently seized by 'those awful tremors' (414). Such an admission complicates a straightforward reading of domestic criminality by suggesting that his infection with tropical illness might have contributed to his behaviour. Colville's 'awful tremors' might here allude to the 'epileptiform seizures' of late-stage sleeping sickness, which Manson considered to be 'by no means rarely' accompanied by 'maniacal outbursts' that can include 'delusions of all sorts, hallucinations, homicidal or suicidal impulses'. ${ }^{108}$ By obliquely connecting this tropical disease with a crime of passion, Meade and Halifax played into a wider narrative pattern that dramatised sleeping sickness as a form of tropical violence-a concept I explore further in the following chapter.

Richard Austin Freeman also drew on the narrative potential of sleeping sickness in his 1912 novel The Mystery of 31 New Inn. The case, ostensibly about a legal problem concerning the details and wording of a will, hinges on a medical diagnosis that reveals an elaborate ruse designed to disguise murder as death from chronic tropical illness. Briefly, Dr Christopher Jervis, a London doctor working late one night as a locum, is called to visit the house of a German man named Mr Weiss. Weiss's friend, 'Mr Graves', is deathly ill and will only permit to be examined by a doctor on the agreement that the doctor does not know who he is, where he lives, or anything about him. This is afforded by a carriage with blacked out windows and an erratic and looping trajectory taken by the coachman. $\mathrm{Mr}$ Weiss describes Mr Graves's condition as alternating between a state of stupor and an almost normal health condition. When Jervis first lays eyes on Graves, he immediately perceives that his 'dreamy, somnolent, and lethargic state' is 'as if under the influence of some narcotic', and quickly comes to a diagnosis of opium or morphine poisoning. ${ }^{109}$ Weiss is unsatisfied with this answer however and after trying to coax Jervis in a different

${ }^{108}$ Patrick Manson, 'A Clinical Lecture on the Sleeping Sickness. Delivered at Charing Cross Hospital, October 1898' Journal of Tropical Medicine (December 1898), 121-28 (p. 125). Also in British Medical Journal (3 December 1898) 1672-77.

${ }^{109}$ R. Austin Freeman, The Mystery of 31 New Inn (loc. 12740). 
direction eventually asks him directly if he has any experience with sleeping sickness. Jervis notes that at the time of the case

practically nothing was known about the disease. It was a mere pathological curiosity, almost unheard of except by a few practitioners in remote parts of Africa, and hardly referred to in the textbooks. (loc. 12819)

Weiss does the diagnostic work for Jervis by informing him that Graves has recently been in West Africa 'where this disease occurs' and that it is 'invariably fatal, sooner or later'. Weiss has in fact (as Jervis correctly surmised) been dosing Graves with morphine. He exploits the obscurity of sleeping sickness to try to trick Jervis into making an erroneous diagnosis; however, the plan backfires because the symptoms seem contradictory and sleeping sickness seems too improbable a solution. As his friend detective Thorndyke asserts: 'the probabilities are against sleeping sickness $[\ldots]$ common sense of the matter is therefore that we adopt morphine poisoning as our working diagnosis [...] For medical purposes you adopted the more probable view and dismissed the less probable' (35).

The apparent 'probability' of the poisoning diagnosis relies on the presence of one symptom: contraction of the pupils, which is not associated with sleeping sickness, but is associated with morphine poisoning. Jervis asks his friend 'medical jurispractitioner' Dr John Thorndyke, to consult on the case owing to his ability to 'view things from a radically different standpoint and [bring] a new and totally different kind of knowledge into the case'-a knowledge, which lawyer Mr Marchmont describes as 'a positive encyclopaedia of [the] out-of-the-way and unexpected' kind. This admission offers a striking parallel to Stamford's description of Holmes in A Study in Scarlet: 'he has amassed a lot of out-of-the-way knowledge which would astonish his professors'. ${ }^{110}$ This description is repeated in a later story when Holmes himself admits: 'I hold a vast store of out-of-theway knowledge'. ${ }^{111}$ Such out-of-the-way knowledge is invaluable when appraising an out-of-the-way disease like sleeping sickness.

Freeman, like Conan Doyle, was a trained medical practitioner who entered the colonial services in 1887 and spent several years as an assistant surgeon in and around West Africa. He was invalided home with

${ }^{110}$ Doyle, 'A Study in Scarlet', p. 10.

${ }^{111}$ Arthur Conan Doyle, 'The Lion's Mane' The Complete Stories of Sherlock Holmes (1926; Ware: Wordsworth Editions, 2008) pp. 1360-73 (p. 1368). 
blackwater fever (a complication of malaria) in 1891 and after a brief stint in London medical practice began to write detective fiction. Like his contemporary, he was attracted by the imaginative continuities between diagnosis and detection. In 1898, he published Travels and Life in Ashanti and Jaman, which contained a chapter on malaria advised upon by Patrick Manson, a detail that suggests an intimate familiarity with the work of Manson, Ross, and parasitology research more generally. Freeman was (perhaps significantly given his story's German antagonist) the AngloGerman boundary commissioner of the Gold Coast and in the introduction places himself in the position of the 'scientific traveller' or 'anthropologist'. ${ }^{112}$

It was during his travels in Ashanti and Jaman that he likely encountered the disease that inspired part of the plot for The Mystery of $31 \mathrm{New}$ Inn. Freeman first tried it out in short story form as ' 31 New Inn' in 1905-the first Thorndyke story he wrote-and adapted it into a full novel six years later. In the novel, Thorndyke teaches Jervis a tracking technique to map his blind journey, using a modified wooden board with a compass attached. The 'experiment' is one, as Freeman proudly tells us in the preface to the novel, that he devised and carried out himself during his time in West Africa. The track chart and route map produced from the process were used to map Ashanti and the surrounding region and were subsequently published by the Royal Geographical Society, compiled into a map by the intelligence branch of the War Office, and accompanied his Travels in Ashanti and Jaman. Freeman thus mobilises a technique for mapping the far interior of Africa to cartographically illuminate the English capital in his fiction, an experimentation in form that imaginatively explores the limits of the scientific method.

The legacies of the entanglements between the tropics, medicine, and crime fiction analysed in this chapter are visible in popular conceptions of diagnostic medicine today, in which the patient is frequently decentred and diagnosis is framed as the solution to a pathological enigma-as one practitioner characterises it: 'diagnosing an illness is often like trying to put together a complicated jigsaw puzzle'. ${ }^{113}$ Such approaches posit a 'one

${ }^{112}$ R. Austin Freeman, Travels and Life in Ashanti and Jaman (Westminster: Archibald Constable and Co., 1898) p. xvii.

${ }^{113}$ R. E. Peschel and E. Peschel, 'What Physicians Have in Common with Sherlock Holmes: A Discussion Paper' Journal of the Royal Society of Medicine 82 (January 1989) 33-36 (p. 33). 
illness, one solution' model that discourages a multi-systems approach to health and encourages unrealistic expectations of standard medical practice. In addition to the dizzying array of cultural artefacts and franchises that owe their genealogy to Sherlock Holmes, the 'great detective' is still routinely invoked as a model for evidence-based medicine. His aphorisms inform models of diagnostic reasoning, and in one article, he is even used as a tool with which to explore 'the cognitive processes and structures underlying expert behaviour'. ${ }^{114}$ In order to fully appreciate the enduring appeal of Holmes - and the doctor-detective dyad more broadly-we must first appreciate the shifting medical and imperial contexts that produced him. Holmes holds cultural currency not simply as an idealisation of science, or as a reductive metaphor for domestic authority, but as a rich and contradictory archetype that articulates our perennial desire for a 'complete form of knowledge'.

${ }^{114}$ André Didierjean and Fernand Gobet, 'Sherlock Holmes - an Expert's View of Expertise’ British Journal of Psychology 99.1 (February 2008) 109-25.

Open Access This chapter is licensed under the terms of the Creative Commons Attribution 4.0 International License (http://creativecommons.org/licenses/ by $/ 4.0 /$ ), which permits use, sharing, adaptation, distribution and reproduction in any medium or format, as long as you give appropriate credit to the original author(s) and the source, provide a link to the Creative Commons licence and indicate if changes were made.

The images or other third party material in this chapter are included in the chapter's Creative Commons licence, unless indicated otherwise in a credit line to the material. If material is not included in the chapter's Creative Commons licence and your intended use is not permitted by statutory regulation or exceeds the permitted use, you will need to obtain permission directly from the copyright holder.

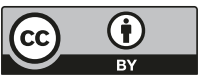

